\title{
Jarosław Odachowski
}

Uniwersytet Wrocławski

e-mail: jaroslaw.odachowski@interia.pl

ORCID: 0000-0002-9396-1470

\section{ZNACZENIE WYTYCZNYCH \\ W KONTEKŚCIE PUBLICZNEGO NADZORU NAD RYNKIEM ZAMÓWIEŃ PUBLICZNYCH*}

\section{SIGNIFICANCE OF GUIDELINES \\ IN THE CONTEXT OF PUBLIC OVERSIGHT OVER THE PUBLIC PROCUREMENT MARKET}

DOI: $10.15611 / \mathrm{pn} .2018 .540 .19$

JEL Classification: K23

Streszczenie: W procesie wdrażania funduszy unijnych ważną rolę odgrywają postanowienia prawa powszechnie obowiązującego - obejmujące zarówno prawo UE, jak i prawo krajowe. O ile specyfika ich i znaczenie w zakresie problematyki funduszy unijnych nie budzi większych wątpliwości, o tyle zwrócić uwagę trzeba na specyficzne i typowe dla tej sfery regulacje prawne. Należą do nich wytyczne. Ich kształt prawny (w tym kwestia wiążącej mocy), zakres regulacji, jak też rola w systemie wdrażania środków unijnych budzi szereg wątpliwości prawnych. Przedmiotem niniejszych rozważań będzie problematyka wytycznych dotyczących zamówień publicznych - w kontekście publicznego nadzoru nad rynkiem zamówień publicznych. W rozpatrywanym zakresie kluczowe znaczenie będzie miało ustalenie charakteru prawnego, jak też roli, jaką odgrywają wytyczne w sferze prawidłowego realizowania zamówień publicznych.

Słowa kluczowe: wytyczne, publiczny nadzór, zamówienia publiczne, rynek zamówień publicznych, fundusze unijne.

Summary: There is an important role of law regulations currently in force (both UE law and national law) in the process of the implementation of European Union funds. There are not many concerns about their specificity and importance within the range of the problem of EU funds. However, there is a necessity to analyse other kinds of regulations - guidelines. Their legal form (including a question of binding nature), adjustment range and position in the system of implementation of UE resources are connected with several legal problems. The article is devoted to the question of guidelines in the area of public procurement, in the context of public oversight over the public procurement market. There is a need to analyse legal nature and the role of guidelines in the field of correct implementation of public procurements.

Keywords: guidelines, public oversight, public procurement, public procurement market, UE funds.

* Artykuł powstał w ramach projektu badawczego SONATA BIS finansowanego ze środków Narodowego Centrum Nauki, na podstawie decyzji nr DEC-2014/14/E/HS5/00845, umowa nr UMO$-2014 / 14 / \mathrm{E} / \mathrm{HS} 5 / 00845$. 


\section{Uwagi ogólne}

W procesie wdrażania funduszy unijnych ${ }^{1}$ ważną rolę odgrywają postanowienia prawa powszechnie obowiązującego, które z jednej strony określają zasady i strukturę organizacyjną procesu realizacji projektów współfinansowanych ze środków UE (w tym system realizacji programu operacyjnego), z uwzględnieniem kwestii wyznaczenia zadań poszczególnych instytucji objętych ww. strukturą i ich stosownych kompetencji ${ }^{2}$, z drugiej zaś - wspomniane przepisy kształtują sytuację prawną beneficjentów środków unijnych w kontekście ich praw i obowiązków w ramach realizacji tych projektów. Przywołane unormowania prawne obejmują zarówno prawo UE (w tym rozporządzenia i dyrektywy), jak i prawo krajowe (ustawy, rozporządzenia wykonawcze itd.).

O ile specyfika ich i znaczenie w zakresie problematyki funduszy unijnych nie budzi większych wątpliwości, o tyle zwrócić uwagę trzeba na specyficzne i typowe dla tej sfery regulacje prawne. Należą do nich wytyczne. Ich kształt prawny (w tym kwestia wiążącej mocy), zakres regulacji, jak również rola w systemie wdrażania środków unijnych budzi wiele wątpliwości prawnych. Należy zatem rozważyć wspomniane kwestie w ujęciu zarysowanych wyżej dwu płaszczyzn prawnych: organizacji systemu realizacji projektów z funduszy UE, jak też praw i obowiązków podmiotów realizujących te projekty ${ }^{3}$.

Przedmiotem niniejszych rozważań będzie problematyka wytycznych dotyczących zamówień publicznych - w kontekście publicznego nadzoru nad rynkiem zamówień publicznych. W rozpatrywanym zakresie kluczowe znaczenie będzie miało ustalenie charakteru prawnego, jak również roli, jaką odgrywają wytyczne w sferze prawidłowego realizowania zamówień publicznych ${ }^{4}$.

${ }^{1}$ Szerzej na temat funduszy unijnych: M. Gwizda, M. Kosewska-Kwaśny, S. Żółciński (red.), 2014, Fundusze UE 2014-2020. Nowa perspektywa - nowe możliwości, Warszawa; B. Jóźwik, M. Sagan, T. Stępniewski (red.), 2012, Polityka spójności Unii Europejskiej. Doświadczenia, wnioski i rekomendacje na lata 2014-2020, tom I: Wybrane problemy realizacji polityki spójności w Unii Europejskiej, Wydawnictwo KUL, Lublin; R. Pawlicki, 2014, Strategia finansowa dla Polski 2014-2020. Fundusze unijne dla przedsiębiorczych, Difin SA, Warszawa; J.W. Tkaczyński, M. Świstak, E. Sztorc, 2013, Projekty europejskie. Praktyczne aspekty pozyskiwania i rozliczania dotacji unijnych, C.H. Beck, Warszawa 2011; J.W. Tkaczyński, M. Świstak, 2013, Encyklopedia polityki regionalnej i funduszy europejskich, C.H. Beck, Warszawa.

${ }^{2}$ Zob. np.: J. Odachowski, 2012, Instytucje uczestniczace $w$ systemie zarzadzania $i$ wdrażania bezzwrotnych środków unijnych, [w:] W. Miemiec (red.), Europejskie bezzwrotne źródła finansowania polityki regionalnej w Polsce. Aspekty prawnofinansowe, Oficyna Wydawnicza UNIMEX, s. 133-154.

${ }^{3}$ Zob. np.: J. Odachowski, 2012, Wytyczne i dokumenty programowe, [w:] W. Miemiec (red.), Europejskie bezzwrotne źródła finansowania polityki regionalnej w Polsce. Aspekty prawnofinansowe, Oficyna Wydawnicza UNIMEX, s. 108-132.

${ }^{4}$ Szerzej o konieczności stosowania prawa UE i prawa krajowego: P. Soszyńska-Purtak, Kontrola zamówień publicznych a korekty finansowe, cz. I, ABC - Komentarz praktyczny, LEX/el. 


\section{Charakter prawny wytycznych w projektach unijnych}

Zgodnie z art. 2 pkt 32 Ustawy z dnia 11 lipca 2014 r. o zasadach realizacji programów w zakresie polityki spójności finansowanych w perspektywie finansowej 2014-20205 (dalej: ustawa wdrożeniowa) przez „wytyczne” należy rozumieć „,instrument prawny określający ujednolicone warunki i procedury wdrażania funduszy strukturalnych i Funduszu Spójności skierowane do instytucji uczestniczących w realizacji programów operacyjnych oraz stosowane przez te instytucje na podstawie właściwego porozumienia, kontraktu terytorialnego albo umowy oraz przez beneficjentów na podstawie umowy o dofinansowanie projektu albo decyzji o dofinansowaniu projektu".

W literaturze słusznie się wskazuje, że „wytyczne nie należą do konstytucyjnego katalogu źródeł prawa powszechnie obowiązującego ${ }^{6}$. Stanowią natomiast akty prawa wewnętrznego kierowane do instytucji uczestniczących we wdrażaniu i realizacji programów operacyjnych (instytucji zarządzających, instytucji pośredniczących lub instytucji wdrażających), podległych lub nadzorowanych przez ministra właściwego do spraw rozwoju regionalnego albo tych, z wymienionych instytucji, którym na podstawie porozumienia albo umowy zostały powierzone określone zadania $\mathrm{W}$ zakresie przygotowania lub realizacji danego programu operacyjnego. W stosunku do tych podmiotów postanowienia zawarte $\mathrm{w}$ wytycznych horyzontalnych [od 2.9.2017 r. : «wytycznych»- J.O.] są wiążące” ${ }^{7}$. Słusznie podkreśla się, że „wytyczne mają charakter instrukcyjny, wyjaśniający, interpretacyjny czy rekomendacyjny, a więc trudno odnaleźć w ich treści cechy aktu normatywnego". Nie ulega zarazem wątpliwości, że treść wytycznych winna być zgodna z regulacjami o wyższej mocy prawnej ${ }^{10}$.

\footnotetext{
${ }^{5}$ Dz.U.2018.1431 t. j.
}

${ }^{6}$ Orzecznictwo zwraca uwagę, że tak określone dokumenty nie mieszczą się w katalogu źródeł prawa powszechnie obowiązującego (wyrok NSA z dnia 10 sierpnia 2011 r. w sprawie II GSK 1578/11 - dostępny w Centralnej Bazie Orzeczeń Sądów Administracyjnych). Wytyczne zostały zaliczone do źródeł prawa administracyjnego w szerokim znaczeniu (wyroki NSA: z dnia 29 kwietnia 2010 r. w sprawie II GSK 371/10 i z dnia 27 października 2010 r. w sprawie II GSK 1097/10 - dostępne w Centralnej Bazie Orzeczeń Sądów Administracyjnych). Podaję za: M. Dołowiec, D.E. Harasimiuk, M. Metlerska-Drabik, J. Ostałowski, R. Poździk, [w:] R. Poździk (red.), 2016, Komentarz do ustawy o zasadach realizacji programów w zakresie polityki spójności finansowanych $w$ perspektywie finansowej 2014-2020, Wydawnictwo Sejmowe, LEX/el.

${ }^{7}$ Art. 1 Ustawy z dnia 7 lipca 2017 r. o zmianie ustawy o zasadach realizacji programów w zakresie polityki spójności finansowanych w perspektywie finansowej 2014-2020 oraz niektórych innych ustaw (Dz.U.2017.1475).

${ }^{8}$ J. Jaśkiewicz, 2014, Zasady realizacji programów w zakresie polityki spójności finansowanych w perspektywie finansowej 2014-2020. Komentarz, LEX/el.

${ }^{9}$ M. Dołowiec, D.E. Harasimiuk, M. Metlerska-Drabik, J. Ostałowski, R. Poździk, wyd. cyt.

${ }^{10} \mathrm{~W}$ orzecznictwie podkreśla się, że tworzony i stosowany na podstawie wytycznych wzorzec działania organów administracji publicznej nie był dla sądów administracyjnych wiążący w tym sensie, że wymagał poddania ocenie pod względem zgodności z przepisami powszechnie obowiązującymi. Za- 
Wytyczne pełnią ważną funkcję w zakresie sprawnego funkcjonowania systemu organizacyjnego wdrażania unijnych funduszy. Z punktu widzenia swojego celu treściowego ich istotą jest (zgodnie z podaną wyżej definicją) określenie ujednoliconych warunków i procedur wdrażania funduszy strukturalnych i Funduszu Spójności. $Z$ kolei biorąc pod uwagę funkcję, jaką mogą pełnić, podkreślić należy, że rozwijają one postanowienia aktów o wyższej mocy prawnej.

Istotną kwestią, wpływającą na istnienie ww. systemu, jest problem wiążącej mocy wytycznych. Jak wskazano wyżej - nie budzi wątpliwości, że związane ich treścią są instytucje uczestniczące w tym systemie. Zupełnie inaczej należy podejść do kwestii możliwości regulacji sytuacji prawnej podmiotów realizujących projekty unijne. $Z$ racji tego, że nie są one instytucjonalnie czy organizacyjnie związane $\mathrm{z}$ instytucjami odpowiedzialnymi za funkcjonowanie systemu w praktyce wdrażania funduszy unijnych ${ }^{11}$, wątpliwości budziło dopuszczenie uregulowania praw i obowiązków beneficjentów poza systemem źródeł powszechnie obowiązującego prawa - w kontekście zgodności z art. 87 Konstytucji RP. W tej kwestii Trybunał Konstytucyjny jednoznacznie odrzucił możliwość nakładania na podstawie wytycznych praw lub obowiązków na beneficjentów ${ }^{12}$.

Słusznie się wskazuje, że w przypadku określania statusu prawnego podmiotów gospodarczych w zakresie unijnych funduszy ważniejsze jest przestrzeganie regulacji statuujących obowiązujący w porządku prawnym RP system norm prawnych (w tym: w zakresie rodzajów źródeł prawa, ich hierarchii czy też materii, jaka może być normowana przez dany rodzaj źródła prawa) niż kwestia skuteczności, efektywności czy szybkości procesu wdrażania środków unijnych - gdzie świetnie się sprawdzają w tym zakresie wytyczne ${ }^{13}$. Trafny jest pogląd, iż „ustawowe cele polityki rozwoju kraju nie mogą być osiągane za pomocą instrumentów prawnych niezgodnych z ustawą zasadniczą"14.

tem treść wytycznych nie mogła być elementem obojętnym dla kontroli legalności prowadzonej przez sądy administracyjne (postanowienie NSA z dnia 6 maja 2010 r. w sprawie II GSK 282/10; wyrok WSA w Warszawie z dnia 14 lipca 2010 r. w sprawie V SA/Wa 1333/10, dostępne w Centralnej Bazie Orzeczeń Sądów Administracyjnych). Z kolei zobowiązanie beneficjenta do stosowania regulacji przyjętych przez drugą stronę umowy o dofinansowanie jest objęte autonomią stron pod warunkiem, że wytyczne nie naruszają norm bezwzględnie obowiązujących zawartych w aktach powszechnie obowiązujących (wyrok NSA z dnia 8 maja 2014 r. w sprawie II GSK 249/13, dostępny w Centralnej Bazie Orzeczeń Sądów Administracyjnych). Za: M. Dołowiec, D.E. Harasimiuk, M. Metlerska-Drabik, J. Ostałowski, R. Poździk, wyd. cyt.

${ }^{11}$ Biorąc pod uwagę również poprzedni okres programowania 2007-2013.

${ }^{12}$ Wyrok TK z dnia 12 grudnia 2011 r., P 1/11 (OTK-A 2011/10/115). Zob. też: Ł.M. Wyszomirski, Glosa do wyroku TK z dnia 12 grudnia 2011 r., P 1/11 (FP.2012/5/52-60); G. Wierczyński, Glosa do wyroku TK z dnia 12 grudnia 2011 r., P 1/11 (Prz. Sejm. 2012/5/167-176).

${ }^{13}$ Zob.: wyrok TK z dnia 12 grudnia 2011 r., P 1/11 (OTK-A 2011/10/115).

${ }^{14}$ K. Wlaźlak, Glosa do wyroku TK z dnia 12 grudnia 2011, P 1/11 (PiP 2013/8/129-134); P. Krzykowski, 2012, Sądowa kontrola administracji o negatywnej ocenie projektu $w$ świetle ustawy z dnia 6 grudnia 2006 r. o zasadach prowadzenia polityki rozwoju, [w:] Kryzys prawa administracyjnego?, t. I: Jakość prawa administracyjnego, D.R. Kijowski, A. Miruć, A. Suławko-Karetko (red.), Warszawa, 
W praktyce realizacji projektów uzyskujących dofinansowanie z funduszy UE w treści umów o dofinansowaniu (odpowiednio decyzji o dofinansowaniu) znajdują się zapisy zobowiązujące beneficjentów do przestrzegania omawianych wytycznych $^{15}$. Tym samym formalną podstawą zobowiązującą ww. podmioty do stosowania się do wytycznych nie są te akty prawne same w sobie, a treść umów (decyzji). Zasadnie wskazuje się w literaturze, że „wytyczne nie stanowią samoistnej podstawy do przyznawania praw lub nakładania obowiązków na inne podmioty"16.

W kontekście powyższych rozważań warto, z jednej strony, zwrócić uwagę na konieczność informowania beneficjentów o obowiązku stosowania się do wytycznych w momencie podpisania umowy (wydania decyzji) - mimo oczywistej konieczności zapoznawania się z treścią projektów wszelkich umów cywilnoprawnych przez podmioty zamierzające zawrzeć takie umowy. $Z$ drugiej strony zaś, istotne znaczenie ma także umożliwienie beneficjentom zapoznania się ze wszystkimi wiążącymi ich wytycznymi - przez różne formy udostępnienia ich treści tym podmiotom. Nie może jednak ulegać wątpliwości, iż beneficjenci - jako normalni uczestnicy obrotu cywilnoprawnego - winni w tym zakresie ze swej strony dołożyć wszelkich starań, by zapoznać się z treścią wszelkich wiążących unormowań prawnych.

\section{Kwestia rozwijania unormowań o wyższej mocy prawnej}

Istnienie wytycznych w ramach programów operacyjnych oznacza, iż rozwijają one unormowania o wyższej mocy prawnej. Wynika to z samego faktu, iż ich obecność jest przewidziana $\mathrm{w}$ rozważanym systemie. W tym sensie ciężko sobie wyobrazić, że ustawodawca wprowadza do sfery funduszy unijnych analizowaną kategorię unormowań i nie daje możliwości, by wytyczne mogły rozszerzać treść postanowień prawa UE czy krajowych ustaw.

Wytyczne w ramach perspektywy finansowej 2014-2020 (tak jak w poprzedniej) podzielić należy na wytyczne unijne oraz krajowe. W przypadku tych pierwszych warto zwrócić uwagę na Komunikat wyjaśniający Komisji dotyczący prawa wspólnotowego obowiązującego w dziedzinie udzielania zamówień, które nie są lub są jedynie częściowo objęte dyrektywami w sprawie zamówień publicznych ${ }^{17}$.

Warto podkreślić, że do dnia 1 września 2017 r. w ramach programów operacyjnych przewidziane były dwa rodzaje krajowych wytycznych. Pierwszym z nich

s. 658. Zob. też: M. Kasiński, M. Stahl, K. Wlaźlak (red.), Sprawiedliwość i zaufanie do władz publicznych w prawie administracyjnym, 2015, LEX/el.

${ }^{15}$ Tak też: M. Dołowiec, D.E. Harasimiuk, M. Metlerska-Drabik, J. Ostałowski, R. Poździk, wyd. cyt.

${ }^{16}$ Jaśkiewicz, wyd. cyt. Co więcej: instytucje publiczne mogły przez wytyczne określać przesłanki, zasady udzielania wsparcia ze środków unijnych, ale nie ustanawiać praw czy obowiązków dla wnioskodawców (por. wyrok WSA w Poznaniu z dnia 2 czerwca 2011 r. w sprawie III SA/Po 276/11, dostępny w Centralnej Bazie Orzeczeń Sądów Administracyjnych). Za: M. Dołowiec, D.E. Harasimiuk, M. Metlerska-Drabik, J. Ostałowski, R. Poździk, wyd. cyt.

${ }^{17}$ 2006/C 179/02. 
są tzw. wytyczne horyzontalne (w aktualnym stanie prawnym - od dnia 2 września 2017 r. - nazywane wytycznymi). Są one wydawane przez ministra właściwego do spraw rozwoju regionalnego (art. 4 ust. $1 \mathrm{w}$ związku z ust. 2 pkt 3 i art. 5 ustawy wdrożeniowej). Rozpatrując cel i funkcje tych wytycznych, należy zwrócić uwagę na „koordynację realizacji programów operacyjnych” (art. 4 ust. 1), jak też „zapewnienie zgodności sposobu realizacji programów operacyjnych z prawem Unii Europejskiej w zakresie wdrażania funduszy strukturalnych i Funduszu Spójności oraz spełniania wymagań określanych przez Komisję Europejską w tym zakresie, a także zapewnienie jednolitości sposobu realizacji programów operacyjnych i prawidłowości realizacji zadań i obowiązków określonych ustawą" (art. 5 ust. 1). Postanowienie art. 5 ust. 1 (cele szczegółowe) jest zatem rozwinięciem myśli zawartej w art. 4 ust. 1 ustawy wdrożeniowej (cel ogólny). Nie ulega zaś wątpliwości, że wytyczne są skierowane do instytucji uczestniczących w realizacji systemów operacyjnych $(\text { art. } 5 \text { ust. } 2)^{18}$.

Odnosząc powyższe uwagi do wytycznych (horyzontalnych) w zakresie zamówień publicznych, należy wskazać, że są one wydawane wyłącznie przez ministra właściwego do spraw rozwoju regionalnego. Ich celem i funkcją jest problem koordynacji realizacji poszczególnych programów operacyjnych. Nie ulega zatem wątpliwości, że kompetencja do ich wydawania - biorąc pod uwagę konieczność realizacji celu i funkcji - należy do wymienionego centralnego organu administracji rządowej, a nie zarządów województw (instytucji zarządzających regionalnymi programami operacyjnymi ${ }^{19}$ czy np. Prezesa Urzędu Zamówień Publicznych (UZP). Pierwsza kategoria organów nie ma kompetencji w zakresie programów krajowych; z kolei Prezes UZP w sferze unijnych funduszy ma jedynie uprawnienia w dziedzinie zamówień publicznych.

Zestawiając ze sobą aspekt rozwijania postanowień innych aktów prawnych z kwestią koordynacji programów operacyjnych, zauważyć należy, że ustawodawca konkretyzuje, na czym (w przedmiocie treści) ma polegać rozszerzenie unormowań kształtujących system realizacji projektów unijnych. Wpływa on zatem na treść wytycznych przez ukierunkowanie ich szczegółowych postanowień. Oznacza to zatem, że nie wystarczy tylko, by wytyczne były zgodne z normami o wyższej mocy prawnej (ograniczenie związane z hierarchią źródeł prawa), ale muszą zarazem realizować wymogi wskazane w ww. przepisach ustawy wdrożeniowej (ograniczenie treściowe). Rozwinięcie nie może zatem istnieć niejako „samo dla siebie”.

Zarazem nie sposób nie zauważyć, że wypełnienie przez ministra właściwego do spraw rozwoju regionalnego wspomnianych zadań w drodze wydania wytycznych oznacza w konsekwencji rozwinięcie postanowień aktów o wyższej mocy prawnej. Jeśli ustawodawca w art. 4 i 5 ustawy wdrożeniowej przewiduje możliwość koor-

\footnotetext{
${ }^{18}$ Patrz też art. 10 ust. 3 ustawy wdrożeniowej.

${ }^{19}$ Patrz np.: J. Odachowski, G. Karwatowicz, Zarząd województwa jako instytucja zarządzająca regionalnym programem operacyjnym, Samorząd Terytorialny, 2011, nr 7-8, s. 110-119.
} 
dynacji programów operacyjnych w drodze wytycznych, tym samym przewiduje możliwość (czy wręcz konieczność) ich wydania; zarazem jasno należy stwierdzić, że wytyczne - jako kolejne źródło unormowań prawnych - nie mają na celu powtarzania czy cytowania innych regulacji (poza oczywistym brakiem sensu istnienia w takim wypadku nie realizowałyby celu, jakim jest koordynacja), a wprowadzanie nowych - a więc rozwijanie postanowień o wyższej mocy prawnej.

Prawodawca $\mathrm{w}$ ww. przepisach ustawy przyznaje centralnemu organowi administracji rządowej kompetencję fakultatywną ${ }^{20}$; niemniej jednak względy zapewnienia omawianej koordynacji mogą w poszczególnych przypadkach wskazywać na obowiązek wydania w danej dziedzinie wytycznych. W tym sensie ciężko sobie wyobrazić, by ustawodawca uznał, że materia zamówień publicznych jest tak nieistotna, że nie należy wprowadzać dodatkowych regulacji.

Co więcej: ustawa wdrożeniowa - wymieniając sfery tematyczne wytycznych (katalog otwarty ${ }^{21}$ - nie wskazuje expressis verbis dziedziny zamówień publicznych. Mając świadomość istnienia wspomnianego katalogu otwartego ${ }^{22}$, zauważyć zarazem należy istnienie postanowień art. 5 ust. 1 pkt $3^{23}, 5^{24}$ i $7^{25}$. W rozpatrywanym zakresie zwrócić przede wszystkim uwagę trzeba na:

- wytyczne w zakresie kontroli realizacji programów operacyjnych na lata 2014-2020 (art. 5 ust. 1 pkt 3) ${ }^{26}$,

- wytyczne w zakresie kwalifikowalności wydatków w ramach Europejskiego Funduszu Rozwoju Regionalnego, Europejskiego Funduszu Społecznego oraz Funduszu Spójności na lata 2014-2020 (art. 5 ust. 1 pkt 5) ${ }^{27}$ i - wytyczne w zakresie sposobu korygowania i odzyskiwania nieprawidłowych wydatków oraz zgłaszania nieprawidłowości w ramach programów operacyjnych polityki spójności na lata 2014-2020 (art. 5 ust. 1 pkt 7) ${ }^{28}$.

${ }^{20}$ Art. 5 ust. 1: „Minister (...) może wydać wytyczne...”.

${ }^{21}$ Art. 5 ust. 1 pkt 11: ,innych kwestii związanych z realizacją i zamknięciem programów operacyjnych".

${ }^{22}$ Co teoretycznie dałoby możliwość wydania wytycznych traktujących o tematyce zamówień publicznych na podstawie cytowanego wyżej pkt 11.

${ }^{23}$ „kontroli realizacji programów operacyjnych”.

${ }^{24}$ „kwalifikowalności wydatków w ramach programów operacyjnych”.

25 „korekt finansowych w ramach programów operacyjnych”.

${ }^{26}$ Dostępne na stronie: https:/www.funduszeeuropejskie.gov.pl/strony/o-funduszach/dokumenty/ wytyczne-ministra-infrastruktury-i-rozwoju-w-zakresie-kontroli-realizacji-programow-operacyjnychna-lata-2014-2020/ (13.02.2019).

${ }^{27}$ Dostępne na stronie: https://www.funduszeeuropejskie.gov.pl/strony/o-funduszach/dokumenty/wytyczne-w-zakresie-kwalifikowalnosci-wydatkow-w-ramach-europejskiego-funduszu-rozwojuregionalnego-europejskiego-funduszu-spolecznego-oraz-funduszu-spojnosci-na-lata-2014-2020/ (13.02.2019).

28 Dostępne na stronie: https://www.funduszeeuropejskie.gov.pl/strony/o-funduszach/dokumenty/ wytyczne-w-zakresie-sposobu-korygowania-i-odzyskiwania-nieprawidlowych-wydatkow-oraz-raportowania-nieprawidlowosci-w-ramach-programow-operacyjnych-polityki-spojnosci-na-lata-2014-2020/ (13.02.2019). 
Pamiętać również należy, że koordynowanie programów operacyjnych nie następuje tylko przez instytucję prawną wytycznych. Nie ulega wątpliwości, że realizacja przywołanego wyżej celu ogólnego następuje już na poziomie tworzenia prawa UE (np. rozporządzenia, dyrektywy ${ }^{29}$ ) czy choćby ustaw ${ }^{30}$ i rozporządzeń - wszak wszystkie te rodzaje aktów normatywnych wprowadzają jednolite dla programów operacyjnych rozwiązania prawne. Z kolei co do celów szczegółowych ich istota łączy się $\mathrm{z}$ koniecznością wykorzystania innych unormowań prawnych - w tym wytycznych ${ }^{31}$.

Drugim rodzajem wytycznych - do 1 września 2017 r. - były tzw. wytyczne programowe (art. $7^{32}$ ). Były one wydawane przez instytucje zarządzające krajowymi albo regionalnymi programami operacyjnymi. Dotyczyły „kwestii szczegółowych dla danego programu operacyjnego"33 i musiały być zgodne między innymi z treścią wytycznych horyzontalnych. Ich istota - w przeciwieństwie do tych wyżej omówionych - ogniskowała się na konkretnym programie operacyjnym (w doktrynie podkreślano, że chodzi o „decentralizację koordynacji” "34, jak też kwestię unormowania ,zagadnień specyficznych dla danego programu operacyjnego oraz nieuregulowanych w ogóle lub tylko częściowo na poziomie horyzontalnym" ${ }^{35}$; orzecznictwo wskazywało, że ,wytyczne programowe stanowią instrument realizacji krajowego albo regionalnego programu operacyjnego i mimo że nie są źródłem prawa powszechnie obowiązującego, to jednak ze względu na cel, jakiemu służą, stanowią ważny dokument systemu realizacji programu operacyjnego" ${ }^{36}$ ), stąd stosowne kompetencje przekazano odpowiednim instytucjom zarządzającym.

${ }^{29}$ Zob. np.: Dyrektywa Parlamentu Europejskiego i Rady 2014/24/UE z dnia 26 lutego 2014 r. w sprawie zamówień publicznych, uchylająca dyrektywę 2004/18/WE (Dz.U.UE.L.2017.337.19), jak też Dyrektywa Parlamentu Europejskiego i Rady 2014/25/UE z dnia 26 lutego 2014 r. w sprawie udzielania zamówień przez podmioty działające w sektorach gospodarki wodnej, energetyki, transportu i usług pocztowych, uchylająca dyrektywę 2004/17/WE (Dz.U.UE.L.2017.337.17).

${ }^{30} \mathrm{Na}$ przykład ustawa wdrożeniowa, Ustawa z dnia 29 stycznia 2004 r. Prawo zamówień publicznych - dalej: PZP - (Dz.U.2019.53).

${ }^{31} \mathrm{Na}$ przykład kwestia zapewnienia zgodności sposobu realizacji programów operacyjnych z prawem UE siłą rzeczy nie może nastąpić przez wydanie chociażby rozporządzenia unijnego; z kolei problem zapewnienia jednolitości sposobu realizacji programów operacyjnych i prawidłowości realizacji zadań i obowiązków określonych ustawą wymaga zastosowania innego rodzaju źródła prawa niż ustawy.

${ }^{32}$ Od 2 września 2017 r. uchylony. Zob.: art. 1 Ustawy z dnia 7 lipca 2017 r. o zmianie ustawy o zasadach realizacji programów w zakresie polityki spójności finansowanych w perspektywie finansowej 2014-2020 oraz niektórych innych ustaw (Dz.U.2017.1475).

${ }^{33} \mathrm{~W}$ doktrynie wskazano, iż ,wytyczne programowe stanowią kolejny, bardziej szczegółowy instrument realizacji krajowego albo regionalnego programu operacyjnego": Jaśkiewicz, wyd. cyt.

${ }^{34}$ M. Dołowiec, D.E. Harasimiuk, M. Metlerska-Drabik, J. Ostałowski, A. Wołyniec-Ostrowska, [w:] R. Poździk [red.], Komentarz do ustawy o zasadach realizacji programów w zakresie polityki spójności finansowanych w perspektywie finansowej 2014-2020, Wydawnictwo Sejmowe, 2016, LEX/el.

${ }^{35}$ M. Dołowiec, D.E. Harasimiuk, M. Metlerska-Drabik, J. Ostałowski, A. Wołyniec-Ostrowska, wyd. cyt.

${ }^{36}$ Wyrok NSA w Warszawie z dnia 20 marca 2018 r., I GSK 146/18: Charakter prawny wytycznych programowych. 
W przypadku tej kategorii norm prawnych ustawodawca nie tylko przewidział możliwość rozwijania postanowień o wyższej mocy prawnej, ale zarazem dał możliwość ich różnicowania odnośnie do poszczególnych programów operacyjnych. W rozważanym zakresie prawodawca wprowadził do porządku prawnego unijnych funduszy kolejne źródło regulacji prawnych, które winno było być rozpatrywane na płaszczyźnie tworzenia odrębnych (w odniesieniu do konkretnego programu operacyjnego) systemów norm prawnych.

Jak zostało wskazane powyżej, z dniem 2 września 2017 r. zrezygnowano z instytucji prawnej wytycznych programowych. W uzasadnieniu projektu Ustawy z dnia 7 lipca 2017 r. o zmianie ustawy o zasadach realizacji programów w zakresie polityki spójności finansowanych w perspektywie finansowej 2014-2020 oraz niektórych innych ustaw ${ }^{37}$ nadmieniono, że „,celem projektowanej zmiany jest ograniczenie dokumentów stosowanych przez instytucje systemu realizacji programu operacyjnego oraz uniknięcie ryzyka nakładania tego typu dokumentami obowiązków na beneficjentów”. Co więcej: „rozwiązanie jest zgodne z polityką nienakładania na beneficjentów obowiązków niewynikających bezpośrednio z przepisów prawa powszechnie obowiązującego lub umów (decyzji) o dofinansowanie projektu"38. W literaturze wskazano także na kwestię ryzyka sprzeczności pomiędzy oboma rodzajami wytycznych ${ }^{39}$.

Zdaniem autora kierunek zmian, jakie wprowadził ustawodawca, jest właściwy i pożądany. Ważne znaczenie ma kwestia zmniejszenia liczby regulacji prawnych istniejących w systemie wdrażania środków unijnych. Ma to szczególne znaczenie zwłaszcza dla podmiotów gospodarczych - jako podmiotów zasadniczo słabiej orientujących się w treści rozmaitych unormowań prawnych w ww. zakresie (słabiej niż pracownicy instytucji zarządzających i wdrażających fundusze unijne), jak też jako podmiotów realizujących przez wspomniane projekty wyznaczone przez siebie cele i angażujących własne środki finansowe.

Niemniej jednak trzeba wskazać, że eliminacja omawianej kategorii wytycznych nie zmienia właściwie wspomnianego układu, w którym istnieje wiele różnorodnych regulacji prawnych. Oprócz wytycznych (horyzontalnych) obowiązują choćby postanowienia z zakresu unijnego soft law; w praktyce wdrażania funduszy unijnych istotne znaczenie mają też np. rozmaite interpretacje krajowych organów państwowych (np. ministra właściwego do spraw rozwoju regionalnego), które - choć formalnie nie obowiązują beneficjentó $\mathrm{w}^{40}$ - to w praktyce wpływają na całokształt

${ }^{37}$ Zob. wyżej.

${ }^{38}$ Zob. też: art. 18 i 19 Ustawy z dnia 7 lipca 2017 r. o zmianie ustawy o zasadach realizacji programów w zakresie polityki spójności finansowanych w perspektywie finansowej 2014-2020 oraz niektórych innych ustaw.

${ }^{39}$ Podkreślono, że w tych relacjach nie obowiązuje zasada lex specialis derogat legi generali, gdyż w razie sprzeczności pierwszeństwo mają zawsze zasady uregulowane na poziomie horyzontalnym: M. Dołowiec, D.E. Harasimiuk, M. Metlerska-Drabik, J. Ostałowski, A. Wołyniec-Ostrowska, wyd. cyt.

${ }^{40}$ Często nie znają nawet ich treści. 
działań instytucji systemu zarządzania i kontroli (zwłaszcza w sferze interpretacji przepisów prawnych), a tym samym również na sytuację prawną beneficjentów. Wskazane uwagi dotyczą także kwestii nienakładania na podmioty gospodarcze obowiązków poza sferą regulacji o charakterze powszechnie obowiązującym.

Innym problemem jest kwestia rezygnacji z wytycznych programowych $\mathrm{w}$ trakcie trwania perspektywy finansowej, co nie sprzyja stabilizacji systemu prawnego w dziedzinie unijnych funduszy. W rozważanym zakresie sens mógłby mieć układ, w którym wytyczne te nie obowiązują od początku perspektywy (nie są w jej ramach w ogóle przewidziane); ewentualnie mają zastosowanie do jej końca.

Przykładami wytycznych programowych są: Wytyczne w zakresie kwalifikowalności wydatków w ramach Programu Operacyjnego Infrastruktura i Środowisko na lata 2014-2020 ${ }^{41}$ czy też Wytyczne dotyczące udzielania zamówień publicznych w ramach Regionalnego Programu Operacyjnego Województwa Pomorskiego na lata $2014-2020^{42}$.

\section{Wytyczne a nieprawidłowości indywidualne}

Problematyka wytycznych jako aktów prawnych określających prawa i obowiązki beneficjentów rozpatrywana winna być też w kontekście możliwych ich naruszeń przez wspomniane podmioty. Naruszenie wytycznych dotyczących zamówień publicznych prowadzi w konsekwencji do uruchomienia odpowiednich środków nadzorczych (publiczny nadzór nad rynkiem zamówień publicznych).

W ramach wdrażania projektów ze środków unijnych naruszanie wiążących podmioty gospodarcze unormowań łączy się z kwestią występowania nieprawidłowości indywidualnych. Ustawa wdrożeniowa w zakresie definicji wspomnianego pojęcia odwołuje się w art. 2 pkt 14 do postanowienia art. 2 pkt 36 rozporządzenia Parlamentu Europejskiego i Rady (UE) nr 1303/2013 z dnia 17 grudnia 2013 r. ustanawiającego wspólne przepisy dotyczące Europejskiego Funduszu Rozwoju Regionalnego, Europejskiego Funduszu Społecznego, Funduszu Spójności, Europejskiego Funduszu Rolnego na rzecz Rozwoju Obszarów Wiejskich oraz Europejskiego Funduszu Morskiego i Rybackiego oraz ustanawiającego przepisy ogólne dotyczące Europejskiego Funduszu Rozwoju Regionalnego, Europejskiego Funduszu Społecznego, Funduszu Spójności i Europejskiego Funduszu Morskiego i Rybackiego oraz uchylającego rozporządzenie Rady (WE) nr 1083/2006 - tzw. rozporządzenia ogólnego ${ }^{43}$. W jego świetle chodzi o „każde naruszenie prawa unijnego lub prawa krajowego dotyczącego stosowania prawa unijnego, wynikające $\mathrm{z}$ działania lub za-

${ }^{41}$ Dostępne na stronie: https://www.pois.gov.pl/strony/o-programie/dokumenty/wytyczne-wzakresie-kwalifikowania-wydatkow-w-ramach-programu-operacyjnego-infrastruktura-i-srodowisko-2014-2020-1/ (13.02.2019).

${ }^{42}$ Dostępne na stronie: https://www.funduszeeuropejskie.gov.pl/media/15713/ZW_zal_9_Wytyczne_dot_zam_publ.pdf(13.02.2019).

${ }^{43}$ Dz.U.UE.L.2018.291.5. 
niechania podmiotu gospodarczego zaangażowanego we wdrażanie EFSI, które ma lub może mieć szkodliwy wpływ na budżet Unii poprzez obciążenie budżetu Unii nieuzasadnionym wydatkiem"44.

Przywołany przepis wymienia tylko dwa rodzaje źródeł prawa: prawo UE oraz prawo krajowe (w zakresie dotyczącym stosowania unijnego prawa). Obydwa terminy należy interpretować w sposób klasyczny i rozumieć przez nie prawo powszechnie obowiązujące - odpowiednio - traktaty, rozporządzenia czy dyrektywy, jak również z drugiej strony ustawy czy rozporządzenia.

$\mathrm{W}$ ramach tak rozumianych instytucji prawnych nie mieszczą się wytyczne. $\mathrm{Na}$ płaszczyźnie prawa UE zalicza się je do soft law, które wyróżnia się swym formalnie niewiążącym charakterem. $Z$ kolei nie ulega wątpliwości, że wytyczne nie mieszczą się w ramach polskich źródeł prawa powszechnie obowiązującego.

Niemniej jednak należy uznać, że zakres przedmiotowy obu pojęć powinien być szeroko rozumiany i obejmować również wytyczne (mimo że z interpretacji językowej to nie wynika). Oznacza to zatem rozszerzenie katalogu unormowań, których naruszenie może w konsekwencji prowadzić do stwierdzenia wystąpienia nieprawidłowości indywidualnej.

Po pierwsze, należy zauważyć, że w systemie funduszy unijnych występuje wiele rozmaitych przepisów prawnych o różnym charakterze i znaczeniu. Istotną rolę odgrywają takie regulacje, jak wytyczne i dokumenty programowe. Dają one możliwość uszczegółowienia zasad wdrażania projektów współfinansowanych ze środków unijnych przez rozwinięcie unormowań o wyższej mocy prawnej. Wpływają one zatem na kwestię praw i obowiązków podmiotów realizujących powyższe projekty.

Po drugie, istotne znaczenie $\mathrm{w}$ omawianym zakresie ma zagadnienie wiążącej mocy wytycznych. W sytuacji braku ich wiążącego charakteru nie sposób byłoby przypisywać beneficjentom obowiązku ich przestrzegania z zastrzeżeniem zagrożenia określonymi sankcjami i ujęcia ewentualnych naruszeń wytycznych jako nieprawidłowości. Jak wskazano wyżej w ramach rozważań - wytyczne są aktami mającymi wiążący dla ww. podmiotów charakter. Daje to więc możliwość uznawania wspomnianych naruszeń za nieprawidłowości, jak też w dalszym zakresie stosowania określonych środków nadzorczych. Stwierdzić zatem trzeba, że wyjaśnienie omawianej kwestii wiąże się nie tyle z kwestią konieczności posługiwania się regułami wykładni językowej, ile z problemem ustalenia mocy wiążącej poszczególnych unormowań.

Co więcej: warto zwrócić uwagę na niektóre postanowienia art. 2 pkt 36 rozporządzenia, które - posiłkowo - pozwalają potwierdzić zasadność wyżej sformułowanych uwag. Przede wszystkim unijny prawodawca wskazuje, że chodzi o „każde” naruszenie. Słowo „każde” oznacza tu konieczność szerokiego ujmowania unormo-

\footnotetext{
${ }^{44}$ Szerzej na temat nieprawidłowości indywidualnych: J. Odachowski, Irregularities in the Process of Implementation of Projects Co-Financed from EU Funds under the 2014-2020 Financial Perspective - Analysis of Article 24 of the "Implementation Act", [w:] K. Łobos, P. Schiffauer (eds), Between Crisis and Innovation - European Policies Through National and Transnational Perspectives, CeDeWu 2016.
} 
wań prawnych w kontekście konstrukcji prawnej nieprawidłowości indywidualnej. Choć stricte dotyczy ono prawa UE i prawa krajowego (a nie wytycznych), to może jednak sugerować, że należy szeroko rozumieć zakres przedmiotowy regulacji, których naruszenie prowadzi do wystąpienia nieprawidłowości, i tym samym objąć nimi również wytyczne.

Ponadto przywołany przepis wskazuje na regulacje prawa krajowego, które „dotyczą" stosowania prawa unijnego. Znów należy podkreślić, że przytoczone sformułowanie odnosi się do prawa krajowego, które należy tu interpretować wąsko - bez obejmowania nim wytycznych (tym bardziej unijnych). Niemniej jednak również w tej sytuacji można rozważać, czy nie należy rozpatrywanego fragmentu art. 2 pkt 36 rozumieć szeroko: jako nakazującego zaliczać do kategorii unormowań, których naruszenie skutkuje wystąpieniem nieprawidłowości, różnych regulacji rozwijających prawo unijne (,dotyczących”) - a więc również wytycznych.

Reasumując, należy stwierdzić, że: przestrzeganie przez podmioty gospodarcze wyłącznie postanowień wiążącego prawa Unii Europejskiej oraz mającego tę samą moc prawną prawa krajowego (w zakresie dotyczącym stosowania prawa UE) ${ }^{45}$ nie oznacza jeszcze, że nie mogą się one dopuścić nieprawidłowości indywidualnych. Badać w takich przypadkach należy, czy beneficjent przekroczył jakąkolwiek wiążącą go regulację - również ze sfery wytycznych.

Problemem, jaki można zauważyć w kontekście nadzoru nad rynkiem zamówień publicznych, jest brak umiejscowienia w treści art. 2 pkt 36 zapisu o wytycznych. Oznacza to, że ustawodawca unijny - a za nim krajowy - nie wskazują expressis verbis pełnego katalogu unormowań prawnych, których naruszenie prowadzi do stwierdzenia wystąpienia nieprawidłowości indywidualnej.

$\mathrm{Z}$ formalnego punktu widzenia można mówić o braku pewności prawa, gdyż precyzyjne określenie katalogu regulacji prawnych ma w rozważanym przypadku kluczowe znaczenie. Ów brak pewności - teoretycznie - dotyczyć może zarówno instytucji systemu zarządzania i kontroli, beneficjentów realizujących projekty unijne, jak i sądów administracyjnych rozpatrujących sprawy dotyczące wdrażania funduszy unijnych. Z praktycznego punktu widzenia problem w zasadzie dotyczy podmiotów realizujących projekty unijne, które nie zawsze dysponują fachową wiedzą prawniczą (w tym znajomością wszystkich regulacji prawnych $\mathrm{w}$ ramach procesu wdrażania unijnych środków, jak też świadomością znaczenia wytycznych w tym procesie). Istotne znaczenie mają zatem różne działania zmierzające do upowszechniania stosownej wiedzy u beneficjentów.

Warto podkreślić, że w poprzednim okresie programowania (2007-2013) istniały w omawianej sferze podobne regulacje prawne i ta sama praktyka ich interpretacji ${ }^{46}$.

${ }^{45} \mathrm{~W}$ wąskim rozumieniu obu pojęć.

${ }^{46}$ Zob. np.: J. Odachowski, Pojęcie nieprawidłowości wykorzystania przyznanych środków w prawie UE, [w:] W. Miemiec (red.), Europejskie bezzwrotne źródła finansowania polityki regionalnej w Polsce. Aspekty prawno finansowe, Oficyna Wydawnicza UNIMEX, 2012, s. 221-240; G. Karwatowicz, J. Odachowski, Definicja legalna ,nieprawidlowości” w kontekście funduszy strukturalnych 
Oznacza to, że naruszenie treści wytycznych też związane było z koniecznością stwierdzenia, czy w danym wypadku nie doszło do zaistnienia nieprawidłowości. Ustalona w tym okresie praktyka niewątpliwie rzutowała na kształt aktualnie obowiązujących postanowień prawnych (brak zapisów expressis verbis o wytycznych w definicji nieprawidłowości indywidualnej), jak również na sposób ich interpretacji.

Co istotne, największa liczba nieprawidłowości indywidualnych dotyczy sfery zamówień publicznych. Jest to związane z koniecznością stosowania przedmiotowych regulacji $\mathrm{z}$ ww. dziedziny $\mathrm{w}$ ramach wielu projektów unijnych, mnogością unormowań prawnych (w tym ich różną rangą i znaczeniem), częstymi ich zmianami (np. PZP) czy też problemami z ich interpretacją i stosowaniem. Tym bardziej należałoby dbać o precyzyjne definiowanie poszczególnych instytucji prawnych.

Jak wskazano wyżej, ustawodawca krajowy odwołuje się w treści art. 2 pkt 14 ustawy wdrożeniowej do art. 2 pkt 36 rozporządzenia ogólnego. Brak zacytowania odnośnej definicji w treści ustawy, jak też brak jakiejkolwiek jej modyfikacji są zrozumiałe z punktu widzenia roli, funkcji, kształtu prawnego czy też pozycji w hierarchii aktów prawnych rozporządzeń unijnych. Niemniej jednak za dopuszczalne uznać należałoby uzupełnienie w ramach postanowień ustawy wdrożeniowej definicji nieprawidłowości indywidualnej o wytyczne. Rozwiązanie takie nie byłoby niezgodne $\mathrm{z}$ definicją $\mathrm{z}$ art. 2 pkt 36, gdyż prawodawca unijny zakłada szerokie rozumienie zakresu źródeł prawa; ewentualnie daje prawną możliwość jego rozszerzenia przez krajowych ustawodawców.

Analizując przykłady nieprawidłowości indywidualnych w dziedzinie zamówień publicznych - biorąc pod uwagę zapisy wytycznych - należy, po pierwsze, zwrócić uwagę na wspomniany wyżej Komunikat wyjaśniający Komisji dotyczący prawa wspólnotowego obowiązującego w dziedzinie udzielania zamówień, które nie są lub są jedynie częściowo objęte dyrektywami w sprawie zamówień publicznych. W tym zakresie wspomnieć można o niedyskryminacyjnym opisie przedmiotu zamówienia, równym dostępie dla podmiotów gospodarczych ze wszystkich państw członkowskich czy choćby o obowiązku przejrzystości (zagwarantowanie wszystkim potencjalnym oferentom odpowiedniego poziomu upublicznienia informacji umożliwiającego rynkowi otwarcie na konkurencję).

W przypadku wytycznych horyzontalnych trzeba, po pierwsze, rozważyć treść Wytycznych w zakresie kwalifikowalności wydatków w ramach Europejskiego Funduszu Rozwoju Regionalnego, Europejskiego Funduszu Społecznego oraz Funduszu Spójności na lata 2014-2020. W ich świetle przykładami nieprawidłowości mogą być:

- nieuwzględnienie aspektów społecznych przez beneficjenta,

i Funduszu Spójności, Kontrola Państwowa, 2009, nr 4, s. 116-126; G. Karwatowicz, J. Odachowski, Nieprawidłowości $w$ zamówieniach publicznych skutkujące nałożeniem korekt finansowych, Finanse Komunalne, 2009, nr 7-8, s. 88-97; W. Miemiec, Przesłanki determinujące zwrot środków przeznaczonych na finansowanie programów realizowanych przez JST z udziatem bezzwrotnych środków europejskich, Finanse Komunalne, 2012, nr 1-2, s. 34 i n. 
- brak lub nieprawidłowe przeprowadzenie rozeznania rynku czy choćby

- naruszenie zasady konkurencyjności.

Wytyczne w zakresie kontroli realizacji programów operacyjnych na lata 2014-2020 przewidują kontrole dokumentów pod względem prawidłowości przeprowadzenia właściwych procedur $\mathrm{w}$ zakresie udzielania zamówień. Z kolei Wytyczne w zakresie sposobu korygowania i odzyskiwania nieprawidłowych wydatków oraz zgłaszania nieprawidłowości w ramach programów operacyjnych polityki spójności na lata 2014-2020 traktują między innymi o wykrywaniu nieprawidłowości w dziedzinie zamówień publicznych oraz o korektach finansowych ${ }^{47}$. Stosowne zapisy mają także wytyczne programowe.

\section{Wytyczne a nieprawidłowości systemowe}

W ramach systemu realizacji projektów dofinansowywanych ze środków unijnych występują nie tylko nieprawidłowości indywidualne, ale także systemowe. Zgodnie $\mathrm{z}$ art. 2 pkt 15 ustawy wdrożeniowej należy (podobnie jak w przypadku wyżej omówionej kategorii nieprawidłowości) odwołać się do treści rozporządzenia ogólnego - tu: art. 2 pkt 38. W jego świetle przez nieprawidłowość systemową należy rozumieć „każdą nieprawidłowość, która może mieć charakter powtarzalny, o wysokim prawdopodobieństwie wystąpienia w podobnych rodzajach operacji, będącą konsekwencją istnienia poważnych defektów w skutecznym funkcjonowaniu systemu zarządzania i kontroli, w tym polegającą na niewprowadzeniu odpowiednich procedur zgodnie z niniejszym rozporządzeniem oraz z przepisami dotyczącymi poszczególnych funduszy".

Analiza przywołanego postanowienia rozporządzenia ogólnego pozwala zauważyć konstytutywne cechy rozpatrywanej instytucji prawnej. Po pierwsze, chodzi o występowanie nieprawidłowości indywidualnych, co oznacza istnienie związku między obiema kategoriami nieprawidłowości. Po drugie: ustawodawca unijny wskazuje na kwestię powtarzalności tych nieprawidłowości w przypadku struktury prawnej nieprawidłowości systemowych - w opozycji do struktury nieprawidłowości indywidualnych, która zakłada jednorazowość naruszenia prawa. Warto też podkreślić, że źródłem nieprawidłowości systemowych nie są zachowania beneficjentów (co jest immanentną cechą nieprawidłowości indywidualnych), a poważne błędy w funkcjonowaniu systemu zarządzania i kontroli.

W kontekście przywołanej tematyki kluczowe znaczenie mają postanowienia art. 6 ustawy wdrożeniowej ${ }^{48}$. W świetle ust. 1 ,system realizacji programu operacyjnego zawiera warunki i procedury obowiązujące instytucje uczestniczące w re-

${ }^{47}$ Szerzej o korektach finansowych: W. Dzierżanowski, Korekty finansowe jako element systemu kontroli wydatkowania środków unijnych, Zamówienia Publiczne. Doradca, 2011, nr 10, s. 14 i n.

${ }^{48}$ Szerzej: Jaśkiewicz, wyd. cyt.; M. Dołowiec, D.E. Harasimiuk, M. Metlerska-Drabik, J. Ostałowski, A. Wołyniec-Ostrowska, wyd. cyt. 
alizacji programów operacyjnych, obejmujące w szczególności zarządzanie, monitorowanie, sprawozdawczość, kontrolę i ewaluację oraz sposób koordynacji działań podejmowanych przez instytucje”. $Z$ kolei ust. 2 stanowi, że ,podstawę systemu realizacji programu operacyjnego mogą stanowić w szczególności przepisy prawa powszechnie obowiązującego, wytyczne, szczegółowy opis osi priorytetowych programu operacyjnego, opis systemu zarządzania i kontroli oraz instrukcje wykonawcze zawierające procedury działania właściwych instytucji”.

Prawodawca wskazał na: treść systemu (warunki i procedury), podmioty zobowiązane (instytucje uczestniczące w realizacji programów operacyjnych), zakres systemu (np. zarządzanie, monitorowanie, sprawozdawczość) ${ }^{49}$ oraz jego podstawę prawną (np. przepisy prawa powszechnie obowiązującego, wytyczne).

Analizując wskazane wyżej unormowania prawne, zauważyć trzeba, że omawiany system opisywany jest za pomocą szeregu elementów, które pozwalają w konsekwencji poznać i określić całą jego strukturę. Istotne znaczenie ma przede wszystkim wskazanie podstawy prawnej systemu. W tym aspekcie ustawodawca krajowy wymienia - w ramach katalogu otwartego - wiele prawnych regulacji i dokumentów. Warto zauważyć, że wprost wyszczególnia wytyczne (czego nie zrobił w przypadku definicji nieprawidłowości indywidualnej). Podstawy te różnią się pod różnymi względami, biorąc pod uwagę choćby ich wiążący czy niewiążący charakter, znaczenie na płaszczyźnie procesu wdrażania środków unijnych, jak też procedurę ich ustanawiania.

Wymienienie w rozpatrywanym przepisie wytycznych świadczy o ich istotnej roli i znaczeniu w ramach rozpatrywanego systemu (choć można zauważyć też, że prawodawca po prostu wymienia po kolei różne regulacje tego systemu). Można podkreślić, że ich charakter prawny (akty prawa wewnętrznego) jest stworzony do regulowania ,wewnętrznych” kwestii - a takimi są kwestie dotyczące omawianego systemu. Słusznie zatem wskazuje się w doktrynie, że ,wytyczne przynależą do systemu realizacji programu operacyjnego" 50 .

Można by rozważać, czy wymienienie wytycznych w treści art. 6 ustawy wdrożeniowej jest podyktowane chęcią wyjaśnienia wątpliwości związanej z ewentualnym występowaniem wytycznych na płaszczyźnie systemu zarządzania i kontroli. Pogląd ten należałoby uznać za niewłaściwy, gdyż kwestia ta nie budzi żadnych wątpliwości (nie budziła ich również w poprzednim okresie programowania). Zarazem zauważyć należy, że w przypadku definicji nieprawidłowości indywidualnej ustawodawca nie wymienia wytycznych (gdzie w tej sytuacji kwestia roli wytycznych w kontekście istnienia nieprawidłowości indywidualnych teoretycznie mogłaby bu-

${ }^{49}$ Jest to katalog otwarty - użycie przez ustawodawcę sformułowania „W szczególności” oznacza, że system realizacji może dotyczyć również innych zagadnień (np. kwestii nieprawidłowości i korekt finansowych, informacji i promocji itd.). Por.: M. Dołowiec, D.E. Harasimiuk, M. Metlerska-Drabik, J. Ostałowski, A. Wołyniec-Ostrowska, wyd. cyt.

${ }^{50}$ Jaśkiewicz, wyd. cyt. 
dzić wątpliwości), więc trudno byłoby uznać, że ustawa wymienia w art. 6 wytyczne $\mathrm{w}$ celu usunięcia istniejących wątpliwości.

Istnienie wytycznych wpływa też na pozostałe aspekty systemu realizacji programu operacyjnego. Po pierwsze, trzeba wskazać na związek z treścią systemu: warunkami i procedurami. Nie ulega wątpliwości, że w omawianej sferze treść wytycznych może dotyczyć jedynie tych kwestii, gdyż treścią systemu jest wyłącznie problem określenia warunków i procedur (bez znaczenia tu jest, czy wytyczne występują czy nie). Łączy się z tym kolejna kwestia - zakres systemu - gdzie ustawodawca wprowadza otwarty katalog dziedzin. Należy zauważyć, że dotyczą one szczegółowych kwestii funkcjonowania systemu. W tym aspekcie istotną rolę odgrywać mogą wytyczne.

W końcu zwrócić uwagę też trzeba na podmioty zobowiązane. Ustawodawca wymienia tu instytucje uczestniczące w realizacji programów operacyjnych. Artykuł 6 nie określa, o jakie instytucje chodzi, co oznacza, że odpowiedzi należy poszukiwać w innych przepisach prawnych. Nie ulega wszak wątpliwości związanie tych podmiotów treścią wytycznych. Wynika to nie tylko z literalnej treści analizowanego postanowienia ustawy wdrożeniowej, ale także z samej istoty tych unormowań, których zadaniem jest regulacja różnych wewnętrznych procedur i procesów ${ }^{51}$.

Kolejnym problemem jest ustalenie relacji między treścią wytycznych a sytuacją prawną beneficjentów. Warto nadmienić, że ustawodawca w ramach art. 6 nie wymienia tej kategorii w przedmiocie określenia podmiotów związanych ich treścią. Należy zauważyć, że warunki i procedury dotyczą zakresu systemu (np. kwestii zarządzania czy monitorowania), a więc sfer aktywności, za które odpowiadają instytucje zarządzające i wdrażające programy operacyjne, a nie beneficjenci. Stąd trafnie art. 6 przywołuje te instytucje. $Z$ drugiej strony, nie sposób nie zauważyć, że prawny kształt tych płaszczyzn oddziałuje na status beneficjentów. Milczenie ustawodawcy w omawianym aspekcie jest świadomym zabiegiem legislacyjnym, gdyż świadczy o tym, że wytyczne same w sobie nie mają mocy wiążącej dla podmiotów gospodarczych. Związanie ich postanowieniami omawianych unormowań następuje w związku z zawarciem w umowach (decyzjach) o dofinansowanie projektów zapisów o konieczności przestrzegania wytycznych.

Prawodawca wskazuje, że w przypadku nieprawidłowości systemowych chodzi o takie sytuacje, gdy nieprawidłowość indywidualna „może mieć charakter powtarzalny, o wysokim prawdopodobieństwie wystąpienia w podobnych rodzajach operacji”. O ile nieprawidłowość indywidualna występuje już w sytuacji jednorazowego zaistnienia określonego stanu prawnego (każde łączne wystąpienie jej elementów składowych oznaczać będzie pojawienie się tego rodzaju naruszenia prawa), o tyle w przypadku nieprawidłowości systemowych owa «jednorazowość» jeszcze nie

\footnotetext{
${ }^{51}$ Zob.: Charakter prawny wytycznych w projektach unijnych.
} 
musi oznaczać ich wystąpienia. W doktrynie wskazano przykładowo, iż „nieprawidłowość systemowa będzie z reguły zbiorem wielu zdarzeń" 52 .

W dalszej kolejności należy - uwzględniając kontekst konieczności prawidłowej realizacji obowiązków z zakresu zamówień publicznych przez beneficjentów (co może prowadzić do wystąpienia nieprawidłowości indywidualnych) - wskazać przykłady nieprawidłowości systemowych $\mathrm{w}$ związku $\mathrm{z}$ istnieniem wytycznych w dziedzinie zamówień publicznych.

Przede wszystkim trzeba zauważyć, że rozporządzenie ogólne zawiera w swej treści wyłącznie jeden przykład nieprawidłowości systemowej $(, \ldots \mathrm{W}$ tym polegającą na niewprowadzeniu odpowiednich procedur zgodnie z niniejszym rozporządzeniem oraz z przepisami dotyczącymi poszczególnych funduszy") - choć mamy do czynienia $\mathrm{z}$ katalogiem otwartym ${ }^{53}$. W analizowanej sytuacji chodzić będzie o wszelkie wymagane procedury - w tym w sferze zamówień publicznych. Doktryna wskazuje przykładowo ,instrukcje wykonawcze, wytyczne dotyczące sposobu prowadzenia kontroli itp." ${ }^{\prime 5}$. Brak wprowadzenia procedur w treści wytycznych może oznaczać w konsekwencji wystąpienie nieprawidłowości systemowej (ów brak może prowadzić wszak do powtarzalności nieprawidłowości indywidualnych po stronie beneficjentów). Związek między procedurami a wytycznymi wskazany jest w art. 6 ustawy wdrożeniowej.

Pamiętać zarazem należy, że procedury te mogą być wprowadzane do różnych aktów prawnych czy dokumentów w kontekście danego programu operacyjnego nie zawsze w danej sytuacji wprowadzanie odpowiednich regulacji musi dotyczyć wytycznych. Niemniej jednak podany w rozporządzeniu ogólnym rodzaj nieprawidłowości systemowej będzie miał miejsce również, gdy stosowne procedury zostaną zamieszczone np. w treści ustaw, rozporządzeń, ale nie zostaną wprowadzone do treści wytycznych (jeśli było to konieczne).

Innym ważnym przypadkiem nieprawidłowości systemowej jest zagadnienie niewłaściwej interpretacji przepisów prawnych przez instytucje systemu zarządzania i kontroli. Mając na uwadze sferę zamówień publicznych, wspomnieć trzeba o kwestii prawidłowej wykładni zapisów wytycznych.

Nieprawidłowościami systemowymi mogą być też przypadki, w których ww. instytucje tworzą określone unormowania (tu: wytyczne), nie mając stosownego upoważnienia ${ }^{55}$ czy je przekraczając. Odpowiednio należy też zwrócić uwagę na sytuację, gdy dana instytucja tworzy wspomniane unormowania, a których treść narusza regulacje o wyższej mocy prawnej (np. wydanie wytycznych z dziedziny zamówień publicznych naruszających treść przedmiotowych dyrektyw czy PZP). Konsekwencją wspomnianych przypadków mogą być nieprawidłowości indywidu-

${ }^{52}$ M. Dołowiec, D.E. Harasimiuk, M. Metlerska-Drabik, J. Ostałowski, R. Poździk, wyd. cyt.

${ }^{53}$ O czym świadczy zwrot: ,w tym”.

${ }^{54}$ M. Dołowiec, D.E. Harasimiuk, M. Metlerska-Drabik, J. Ostałowski, R. Poździk, wyd. cyt.

${ }_{55} \mathrm{Na}$ przykład wydanie wytycznych dotyczących zamówień publicznych przez instytucję pośredniczącą. 
alne popełniane przez beneficjentów zobowiązanych do stosowania różnorodnych przepisów o zamówieniach publicznych.

Istotna kategoria nieprawidłowości systemowych - odnośnie do wytycznych wiąże się z problematyką kontroli zamówień publicznych. Trzeba zwrócić uwagę na rozmaite przykłady takich naruszeń. Po pierwsze: brak w ogóle kontroli w ramach danego programu operacyjnego ${ }^{56}$. Praktyczne znaczenie mają jednak inne przypadki. Z punktu widzenia podmiotu kontrolowanego można wskazać nieprzeprowadzenie kontroli danego beneficjenta (jeśli to było konieczne); z punktu widzenia zakresu kontroli można wskazać sytuacje, gdy nie przeprowadzono (koniecznej) kontroli wszystkich zamówień udzielonych przez beneficjenta (a tylko niektórych). Odpowiednio też można wskazać przypadki, gdy kontroluje się zamówienia, ale w sposób niepełny (np. nie sprawdza się treści ogłoszeń o zamówieniu). Istotnymi problemami mogą być też: nieprawidłowa interpretacja zapisów wytycznych w kontekście kontroli podmiotu gospodarczego czy ogólna niestaranność osób przeprowadzających kontrolę zamówień.

\section{Podsumowanie}

Specyfiką procesu wdrażania funduszy europejskich jest występowanie w jego ramach różnego rodzaju wytycznych. Ich treść ogniskuje się - z jednej strony - na kształtowaniu systemu organizacyjnego realizacji projektów unijnych, z drugiej zaś - na określeniu praw i obowiązków beneficjentów. Pierwsza płaszczyzna ma stricte wewnętrzny charakter, dotyczący wzajemnych relacji i skorelowanych z nimi kompetencji poszczególnych instytucji. Druga z kolei - zewnętrzny, wiążący ze sobą wspomniane instytucje i podmioty gospodarcze.

Rolą wytycznych jest rozwijanie postanowień o wyższej mocy prawnej - prawa UE czy też krajowych ustaw, rozporządzeń itd. Specyfika realizacji projektów unijnych wymaga istnienia bardzo szczegółowych i kazuistycznych regulacji normujących poszczególne aspekty procesu wdrażania środków unijnych. Istnienie wytycznych w tym systemie powoduje, że ww. akty prawne nie muszą regulować wszystkich wymaganych zagadnień.

Istnienie wytycznych w systemie realizacji funduszy UE łączy się z kwestią ich naruszeń. Niezależnie od dosłownej treści definicji nieprawidłowości indywidualnej nie ulega wątpliwości (podobnie jak w poprzedniej perspektywie finansowej), że naruszanie zapisów wytycznych jest traktowane tak samo jak naruszanie innych unormowań prawnych (np. ustaw). Kluczowe znaczenie w tym zakresie ma kwestia wiążącej dla beneficjentów mocy wytycznych. Nieprzestrzeganie wiążących regulacji tych aktów prowadzi do konieczności zbadania, czy doszło do wystąpienia nieprawidłowości indywidualnej.

\footnotetext{
${ }^{56}$ Uznać trzeba ten przypadek za raczej teoretyczny, gdyż ciężko sobie wyobrazić nieprzeprowadzanie w ogóle kontroli.
} 
Kwestia wykrywania i usuwania ww. nieprawidłowości w kontekście rynku zamówień publicznych łączy się z mechanizmem prawnym nadzoru nad tym rynkiem. Odnosząc się do przeprowadzonych rozważań, uznać trzeba, że uruchomienie stosownych instrumentów prawnych przynależnych do przywołanego mechanizmu następuje nie tylko w przypadku naruszenia przez dany podmiot postanowień prawa powszechnie obowiązującego (np. ustaw krajowych), ale także, gdy nie będą przestrzegane postanowienia przedmiotowych wytycznych.

Powtarzalność wspomnianych nieprawidłowości w połączeniu $\mathrm{z}$ defektami w funkcjonowaniu systemu zarządzania i kontroli prowadzi do stwierdzenia występowania innego typu nieprawidłowości: systemowych. W rozważanym zakresie fakt istnienia $\mathrm{w}$ ramach procesu wdrażania środków unijnych wytycznych jako źródła norm prawnych - w związku z ujmowaniem naruszenia ich jako nieprawidłowości indywidualnych - prowadzi do konieczności uznania związku omawianych źródeł unormowań prawnych z konstrukcją nieprawidłowości systemowych.

Również w tym przypadku zauważyć trzeba związek między istnieniem wytycznych dotyczących zamówień publicznych, ich naruszaniem prowadzącym do występowania nieprawidłowości indywidualnych, jak też następnie systemowych oraz - w końcu - wspomnianym mechanizmem nadzoru nad rynkiem zamówień publicznych. Z racji tego, że ów mechanizm służy - w rozważanym zakresie - wykrywaniu i usuwaniu wszelkich nieprawidłowości systemowych, siłą rzeczy musi on też objąć różne sposoby nieprzestrzegania i naruszania zapisów przedmiotowych wytycznych.

\section{Literatura}

Dołowiec M., Harasimiuk D.E., Metlerska-Drabik M., Ostałowski J., Poździk R., [w:] Poździk R. (red.), 2016, Komentarz do ustawy o zasadach realizacji programów w zakresie polityki spójności finansowanych w perspektywie finansowej 2014-2020, Wydawnictwo Sejmowe, LEX/el.

Dołowiec M., Harasimiuk D.E., Metlerska-Drabik M., Ostałowski J., Wołyniec-Ostrowska A., [w:] Poździk R. (red.), 2016, Komentarz do ustawy o zasadach realizacji programów w zakresie polityki spójności finansowanych w perspektywie finansowej 2014-2020, Wydawnictwo Sejmowe, LEX/el.

Dzierżanowski W., 2011, Korekty finansowe jako element systemu kontroli wydatkowania środków unijnych, Zamówienia Publiczne. Doradca, nr 10, s. 14 i n.

Gwizda M., Kosewska-Kwaśny M., Żółciński S. (red.), 2014, Fundusze UE 2014-2020. Nowa perspektywa-nowe możliwości, C.H. Beck, Warszawa.

Jaśkiewicz J., 2014, Zasady realizacji programów w zakresie polityki spójności finansowanych w perspektywie finansowej 2014-2020. Komentarz, LEX/el.

Jóźwik B., Sagan M., Stępniewski T. (red.), 2012, Polityka spójności Unii Europejskiej. Doświadczenia, wnioski i rekomendacje na lata 2014-2020, tom I: Wybrane problemy realizacji polityki spójności w Unii Europejskiej, Wydawnictwo KUL, Lublin.

Karwatowicz G., Odachowski J., 2009, Definicja legalna „nieprawidłowości” w kontekście funduszy strukturalnych i Funduszu Spójności, Kontrola Państwowa, nr 4, s. 116-126.

Karwatowicz G., Odachowski J., 2009, Nieprawidłowości w zamówieniach publicznych skutkujące nałożeniem korekt finansowych, Finanse Komunalne, nr 7-8, s. 88-97.

Kasiński M., Stahl M., Wlaźlak K. (red.), 2015, Sprawiedliwość i zaufanie do władz publicznych w prawie administracyjnym, LEX/el. 
Krzykowski P., 2012, Sąowa kontrola administracji o negatywnej ocenie projektu w świetle ustawy $z$ dnia 6 grudnia 2006 r. o zasadach prowadzenia polityki rozwoju, [w:] Kijowski D.R., Miruć A., Suławko-Karetko A. (red.), Kryzys prawa administracyjnego?, tom I: Jakość prawa administracyjnego, Warszawa.

Miemiec W., 2012, Przesłanki determinujące zwrot środków przeznaczonych na finansowanie programów realizowanych przez JST z udziałem bezzwrotnych środków europejskich, Finanse Komunalne, nr 1-2, s. 34 i n.

Odachowski J., 2012, Instytucje uczestniczace w systemie zarządzania $i$ wdrażania bezzwrotnych środków unijnych, [w:] Miemiec W. (red.), Europejskie bezzwrotne źródła finansowania polityki regionalnej w Polsce. Aspekty prawnofinansowe, Oficyna Wydawnicza UNIMEX, s. 133-154.

Odachowski J., 2012, Pojęcie nieprawidłowości wykorzystania przyznanych środków w prawie UE, [w:] Miemiec W. (red.), Europejskie bezzwrotne źródła finansowania polityki regionalnej w Polsce. Aspekty prawnofinansowe, Oficyna Wydawnicza UNIMEX, s. 221-240.

Odachowski J., 2012, Wytyczne i dokumenty programowe, [w:] Miemiec W. (red.), Europejskie bezzwrotne źródta finansowania polityki regionalnej w Polsce. Aspekty prawno finansowe, Oficyna Wydawnicza UNIMEX, s. 108-132.

Odachowski J., 2016, Irregularities in the Process of Implementation of Projects Co-Financed from EU Funds under the 2014-2020 Financial Perspective - Analysis of Article 24 of the "Implementation Act”, [w:] Łobos K., Schiffauer P. (eds), Between Crisis and Innovation - European Policies Through National and Transnational Perspectives, CeDeWu, Warszawa.

Odachowski J., Karwatowicz G., 2011, Zarząd województwa jako instytucja zarządzająca regionalnym programem operacyjnym, Samorząd Terytorialny, $\mathrm{nr}$ 7-8, s. 110-119.

Pawlicki R., 2014, Strategia finansowa dla Polski 2014-2020. Fundusze unijne dla przedsiębiorczych, Difin SA, Warszawa.

Soszyńska-Purtak P., Kontrola zamówień publicznych a korekty finansowe, cz. I, ABC - Komentarz praktyczny, LEX/el.

Tkaczyński J.W., Świstak M., Sztorc E., 2011, Projekty europejskie. Praktyczne aspekty pozyskiwania i rozliczania dotacji unijnych, C.H. Beck, Warszawa.

Tkaczyński J.W., Świstak M., 2013, Encyklopedia polityki regionalnej i funduszy europejskich, C.H. Beck, Warszawa.

Wierczyński G., Glosa do wyroku TK z dnia 12 grudnia 2011 r., P 1/11 (Prz.Sejm. 2012/5/167-176).

Wlaźlak K., Glosa do wyroku TK z dnia 12 grudnia 2011, P 1/11 (PiP 2013/8/129-134).

Wyszomirski Ł.M., Glosa do wyroku TK z dnia 12 grudnia 2011 r., P 1/11 (FP.2012/5/52-60).

\section{Akty prawne}

Dyrektywa Parlamentu Europejskiego i Rady 2014/24/UE z dnia 26 lutego 2014 r. w sprawie zamówień publicznych, uchylająca dyrektywę 2004/18/WE, Dz.U.UE.L.2017.337.19.

Dyrektywa Parlamentu Europejskiego i Rady 2014/25/UE z dnia 26 lutego 2014 r. w sprawie udzielania zamówień przez podmioty działające w sektorach gospodarki wodnej, energetyki, transportu i usług pocztowych, uchylająca dyrektywę 2004/17/WE, Dz.U.UE.L.2017.337.17.

Komunikat wyjaśniający Komisji dotyczący prawa wspólnotowego obowiązującego w dziedzinie udzielania zamówień, które nie są lub są jedynie częściowo objęte dyrektywami w sprawie zamówień publicznych, 2006/C 179/02.

Rozporządzenie Parlamentu Europejskiego i Rady (UE) nr 1303/2013 z dnia 17 grudnia 2013 r. ustanawiające wspólne przepisy dotyczące Europejskiego Funduszu Rozwoju Regionalnego, Europejskiego Funduszu Społecznego, Funduszu Spójności, Europejskiego Funduszu Rolnego na rzecz Rozwoju Obszarów Wiejskich oraz Europejskiego Funduszu Morskiego i Rybackiego oraz ustanawiające przepisy ogólne dotyczące Europejskiego Funduszu Rozwoju Regionalnego, Europejskiego Funduszu Społecznego, Funduszu Spójności i Europejskiego Funduszu Morskiego 
i Rybackiego oraz uchylające rozporządzenie Rady (WE) nr 1083/2006 - tzw. rozporządzenie ogólne, Dz.U.UE.L.2018.291.5.

Ustawa z dnia 29 stycznia 2004 r. - Prawo zamówień publicznych, Dz. U., 2019, poz. 53.

Ustawa z dnia 11 lipca 2014 r. o zasadach realizacji programów w zakresie polityki spójności finansowanych w perspektywie finansowej 2014-2020, t.j. Dz. U., 2018, poz. 1431.

Ustawa z dnia 7 lipca 2017 r. o zmianie ustawy o zasadach realizacji programów w zakresie polityki spójności finansowanych w perspektywie finansowej 2014-2020 oraz niektórych innych ustaw, Dz. U., 2017, poz. 1475.

Wytyczne w zakresie kwalifikowalności wydatków w ramach Programu Operacyjnego Infrastruktura i Środowisko na lata 2014-2020, https://www.pois.gov.pl/strony/o-programie/dokumenty/wytyczne-w-zakresie-kwalifikowania-wydatkow-w-ramach-programu-operacyjnego-infrastruktura-isrodowisko-2014-2020-1/ (13.02.2019).

Wytyczne dotyczące udzielania zamówień publicznych w ramach Regionalnego Programu Operacyjnego Województwa Pomorskiego na lata 2014-2020, https://www.funduszeeuropejskie.gov.pl/media/15713/ZW_zal_9_Wytyczne_dot_zam_publ.pdf(13.02.2019).

Wytyczne w zakresie kontroli realizacji programów operacyjnych na lata 2014-2020, https://www. funduszeeuropejskie.gov.pl/strony/o-funduszach/dokumenty/wytyczne-ministra-infrastruk tury-i-rozwoju-w-zakresie-kontroli-realizacji-programow-operacyjnych-na-lata-2014-2020/ (13.02.2019).

Wytyczne w zakresie kwalifikowalności wydatków w ramach Europejskiego Funduszu Rozwoju Regionalnego, Europejskiego Funduszu Społecznego oraz Funduszu Spójności na lata 2014-2020, https://www.funduszeeuropejskie.gov.pl/strony/o-funduszach/dokumenty/wytyczne-w-zakresie-kwalifikowalnosci-wydatkow-w-ramach-europejskiego-funduszu-rozwoju-regionalnegoeuropejskiego-funduszu-spolecznego-oraz-funduszu-spojnosci-na-lata-2014-2020/ (13.02.2019).

Wytyczne w zakresie sposobu korygowania i odzyskiwania nieprawidłowych wydatków oraz zgłaszania nieprawidłowości w ramach programów operacyjnych polityki spójności na lata 2014-2020, https://www.funduszeeuropejskie.gov.pl/strony/o-funduszach/dokumenty/wytyczne-w-zakresiesposobu-korygowania-i-odzyskiwania-nieprawidlowych-wydatkow-oraz-raportowanianieprawidlowosci-w-ramach-programow-operacyjnych-polityki-spojnosci-na-lata-2014-2020/ (13.02.2019).

\section{Orzecznictwo}

Postanowienie NSA z dnia 6 maja 2010 r. w sprawie II GSK 282/10 - dostępne w Centralnej Bazie Orzeczeń Sądów Administracyjnych.

Wyrok NSA z dnia 29 kwietnia 2010 r. w sprawie II GSK 371/10 - dostępny w Centralnej Bazie Orzeczeń Sądów Administracyjnych.

Wyrok WSA w Warszawie z dnia 14 lipca 2010 r. w sprawie V SA/Wa 1333/10 - dostępny w Centralnej Bazie Orzeczeń Sądów Administracyjnych.

Wyrok NSA z dnia 27 października 2010 r. w sprawie II GSK 1097/10 - dostępny w Centralnej Bazie Orzeczeń Sądów Administracyjnych.

Wyrok WSA w Poznaniu z dnia 2 czerwca 2011 r. w sprawie III SA/Po 276/11 - dostępny w Centralnej Bazie Orzeczeń Sądów Administracyjnych.

Wyrok NSA z dnia 10 sierpnia 2011 r. w sprawie II GSK 1578/11, dostępny w Centralnej Bazie Orzeczeń Sądów Administracyjnych.

Wyrok TK z dnia 12 grudnia 2011 r., P 1/11 (OTK-A 2011/10/115).

Wyrok NSA z dnia 8 maja 2014 r. w sprawie II GSK 249/13 - dostępny w Centralnej Bazie Orzeczeń Sądów Administracyjnych.

Wyrok NSA w Warszawie z dnia 20 marca 2018 r., I GSK 146/18. 